\title{
The role of environmental accounting in organizational change: An exploration of Spanish companies
}

Article in Accounting Auditing \& Accountability Journal · April 2001

DOI: 10.1108/09513570110389323 · Source: OAI

CITATIONS

146

5 authors, including:

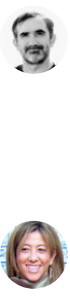

Carlos Larrinaga

Universidad de Burgos

82 PUBLICATIONS 2,980 CITATIONS

SEE PROFILE

\section{Carmen Correa}

Universidad Pablo de Olavide

15 PUBLICATIONS 1,017 CITATIONS

SEE PROFILE

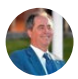

Francisco Carrasco Fenech

Universidad Pablo de Olavide

27 PUBLICATIONS 602 CITATIONS

SEE PROFILE

Francisco Javier CARO GONZALEZ

Universidad de Sevilla

42 PUBLICATIONS 270 CITATIONS

SEE PROFILE

Some of the authors of this publication are also working on these related projects:

Project SANIMUEI. Satisfacción de las necesidades de las mujeres en las empresas informativas View project

Mudimule View project 


\section{Emerald Insight}

\section{Accounting, Auditing \& Accountability Journal}

The role of environmental accounting in organizational change -An exploration of

Spanish companies

Carlos Larrinaga-González Francisco Carrasco-Fenech Francisco Javier Caro-González Carmen Correa-

Ruíz José María Páez-Sandubete

\section{Article information:}

To cite this document:

Carlos Larrinaga-González Francisco Carrasco-Fenech Francisco Javier Caro-González Carmen CorreaRuíz José María Páez-Sandubete, (2001),"The role of environmental accounting in organizational change \#An exploration of Spanish companies", Accounting, Auditing \& Accountability Journal, Vol. 14 Iss 2 pp. 213 $-239$

Permanent link to this document:

http://dx.doi.org/10.1108/09513570110389323

Downloaded on: 01 December 2014, At: 00:07 (PT)

References: this document contains references to 42 other documents.

To copy this document: permissions@emeraldinsight.com

The fulltext of this document has been downloaded 3555 times since 2006*

\section{Users who downloaded this article also downloaded:}

M.R. Mathews, (1997),"Twenty\#five years of social and environmental accounting research: Is there a silver jubilee to celebrate?", Accounting, Auditing \&amp; Accountability Journal, Vol. 10 Iss 4 pp. $481-531$ http:// dx.doi.org/10.1108/EUM0000000004417

Jan Bebbington, (1997),"Engagement, education and sustainability: A review essay on environmental accounting", Accounting, Auditing \&amp; Accountability Journal, Vol. 10 Iss 3 pp. 365-381 http:// dx.doi.org/10.1108/09513579710178115

Rob Gray, Jan Bebbington, (2000),"Environmental accounting, managerialism and sustainability: Is the planet safe in the hands of business and accounting?", Advances in Environmental Accounting \&amp; Management, Vol. 1 pp. 1-44

Access to this document was granted through an Emerald subscription provided by 406779 []

\section{For Authors}

If you would like to write for this, or any other Emerald publication, then please use our Emerald for Authors service information about how to choose which publication to write for and submission guidelines are available for all. Please visit www. emeraldinsight.com/ authors for more information.

\section{About Emerald www.emeraldinsight.com}

Emerald is a global publisher linking research and practice to the benefit of society. The company manages a portfolio of more than 290 journals and over 2,350 books and book series volumes, as well as providing an extensive range of online products and additional customer resources and services.

Emerald is both COUNTER 4 and TRANSFER compliant. The organization is a partner of the Committee on Publication Ethics (COPE) and also works with Portico and the LOCKSS initiative for digital archive preservation. 
*Related content and download information correct at time of download. 


\title{
The role of environmental accounting in organizational change
} An exploration of Spanish companies

\author{
Carlos Larrinaga-González \\ Universidad Carlos III de Madrid, Spain \\ Francisco Carrasco-Fenech \\ Universidad Pablo de Olavide de Sevilla, Spain \\ Francisco Javier Caro-González \\ Universidad de Sevilla, Spain \\ Carmen Correa-Ruíz \\ Universidad Pablo de Olavide de Sevilla, Spain, and \\ José María Páez-Sandubete \\ Universidad de Cádiz, Spain
}

Keywords Environmental accounting, Organizational change, Spain

Abstract Critique originated by earlier theorization of environmental accounting, as a way of building environmentalist visibility of business, led Gray et al., to study environmental accounting in the dynamics of organizational change. They concluded that environmental accounting is being used to "negotiate the conception of the environment" by companies that have not significantly changed. In order to investigate whether Gray et al.'s model and conclusions apply to a different cultural context, we have conducted nine case studies in Spain. We found that Spanish organizations are not truly changing their conventional perception of the environment, even in those cases where generalized structural and organizational changes are taking place. Moreover, the use of environmental accounting is coupled with an attempt to negotiate and control the environmental agenda.

\section{Introduction}

The growing amount of environmental information published in corporate reports, together with the involvement of both professional and academic accountants, has been seen optimistically (Gray, 1990; 1992; Rubenstein, 1992). This literature interprets that the increasing importance of environmental accounting could strengthen an environmentalist point of view of businesses. They view environmental accounting as a Trojan horse (Gray, 1992) into the conventional managerial view of the organizations that is leading us to live in dangerous times (Bebbington et al., 1999).

The authors would like to thank María J. Álvarez, Frank Birkin, Salvador Carmona, two anonymous referees and participants at the 21st Congress of the EAA, for their comments on earlier versions of this paper. We are especially grateful to Carol Adams who guided us through the revision process. We also thank Juan Baños, Sonia Caro, Pilar Fuentes and Rosario Martín for their support in conducting the research. DGICYT (96-1353) and IDR (Universidad de Sevilla) provided financial support for this research.

Environmental accounting in Spain

Submitted September

1998

Revised July 1999,

January 2000

Accepted July 2000 
AAAJ

14,2

214

However, this hopeful view of environmental accounting has generated strong criticism.

First, Tinker et al. (1991) and Cooper (1992), among others, contend that avoiding political issues, research on environmental accounting has failed to articulate the mechanism of social change. In their opinion, environmental accounting is a mere reform of the capitalist system that will reinforce and legitimate the current pattern of environmental destruction. Secondly, inherent in the creation of new areas of expertise by groups such as accountants, there is a danger of premature closure (appropriation) of the environmental agenda, precluding critical disruptions in the conventional organizational behavior visà-vis the natural environment (Power, 1991). These two criticisms, in particular, led Gray et al. (1995) (see also Bebbington et al., 1994) to study environmental accounting practice, and accountants, within the dynamics of organizational change, with a view to showing that "environmental accounting can represent new voices, new visibilities and new discourses which can disrupt and encourage possibilities for change" (Gray et al., 1995, p. 214). Their attempt to provide arguments against those criticisms turned out to be unsuccessful, as they concluded that environmental accounting is currently being used to negotiate and to limit the concept of the environment, and that any form of environmental accounting involves a trade-off between transparency and control. In spite of its interest, Gray et al.'s (1995) stimulating model of organizational change and environmental accounting, has received little attention.

Gray et al.'s (1995) survey is based on the UK and New Zealand. Spanish culture and values differ from those of Anglo-Saxon countries and are closer to those of Latin-European and Latin-American countries (Gray, 1988; Hofstede, 1991). Hofstede's (1991) research was aimed at identifying the structural elements of culture that affect behavior in organizations. He analyzed four factors (power distance, masculinity/femininity, individualism/collectivism and uncertainty avoidance attitude) and grouped countries in different cultural areas. While the UK and New Zealand were located in the "Anglo" area, Spain was placed in the "more developed Latin" area - different in all his cultural values to the "Anglo" - characterized by large power distance, femininity, collectivism and strong uncertainty avoidance.

Gray (1988) hypothesized a relationship between accounting values (secrecy vs transparency, conservatism vs optimism, uniformity vs flexibility and statutory control vs professionalism) and Hofstede's cultural values. He posited that Anglo-Saxon countries and "more developed Latin" countries are characterized by different accounting values, those in the "more developed Latin" countries being secrecy, conservatism, uniformity and statutory control. However, Adams and Kausirikun (2000) have found that German (despite Gray's finding that they are secretive) chemical and pharmaceutical companies show a higher volume of environmental reporting than UK corporations do in the same industry. 
Given the conclusions reported by Gray et al. (1995) and the anomaly revealed by Adams and Kausirikun (2000), there seems to be value in exploring the use of environmental accounting in an entrepreneurial context characterized by the accounting value of secrecy. Would environmental accounting also be used to control the environmental agenda in a secretive accounting setting? This article seeks to answer this question through the analysis of several Spanish case studies.

For that purpose, in section 2, the theories of organizational change developed by Laughlin (1991) and Gray et al. (1995) are described, paying particular attention to their discrepancies. The central body of this article is based on multiple case study research, the methodology of which is presented in section 3. The subsequent sections report on the analysis of the collected data. Section 4 explores whether the theoretical framework of organizational change can explain these cases. This allows us to discuss the role of accounting in the process of (non) change followed by Spanish companies, a task that is undertaken in section 5. Finally, the conclusions are presented in section 6.

\section{Laughlin's model of organizational change and its relationship with Gray et al.'s (1995) theory}

Laughlin (1991) contends that many of the studies of organizational change that were devoted to "Context-free descriptions of change techniques and effects" (p. 209) failed to capture the dynamics involved. Moreover, he advocates that these dynamics must be studied in relation to an environmental disturbance, that is, organizations are naturally change resistant, and will change only when they are forced to do so. However, it is not possible to anticipate which pattern of change each company will follow, once disturbed. To gain more insight into organizational change, Laughlin (1991) looks at theories relating to the organizational components and the different possibilities for change.

Laughlin conceives the organization as being an amalgam of sub-systems, design archetypes and interpretive schemes. The sub-systems are tangible elements such as buildings, behaviors, machines, persons, etc. The design archetypes (intangible structures, information systems, etc.) guide and provide coherence to the organization through a series of underlying values that make up the interpretive schemes (metaphors, beliefs, values, rules, mission statements) which operate as shared fundamental assumptions about the functioning of the other elements of the organization.

Laughlin (1991) points out that organizations are normally balanced and coherent. Only an environmental disturbance will cause changes in the balance of the components of the organization, and then the organization will evolve to a different balanced state. Laughlin (1991) did not concentrate on a single environmental disturbance. However, Gray et al. (1995) studied specifically the response of companies to the disturbance that "a society concerned with the actual state of the natural environment” (p. 218) creates within organizations. When the change cannot be avoided, Laughlin (1991) distinguishes between
Environmental accounting in Spain 
AAAJ

14,2

216

first-order and second-order change. Initially, the organization's participants will attempt to change peripheral components that do not threaten the basic balance of the organization. This is called first-order change or morphostasis that can be characterized as giving things a different appearance, while basically remaining as they have always been (Laughlin, 1991). It is only through a modification of the interpretive schemes that an authentic change can happen, an alteration that penetrates the organizational genetic code in such a way that all future generations will acquire and reflect that change. This second-order change is called morphogenesis (see Figure 1).

Laughlin (1991) found that the language of accounting was the primary vehicle for morphogenetic change in the European Railways case. Accounting was used, not only as a language that enabled the change, but also as a means of taking over as the central element of the interpretive schemes. Then, from an environmentalist point of view, the question - as Gray et al. (1995) asked themselves - is whether environmental accounting is, or could be, an important agent of morphogenesis in those organizations that are changing as a result of the disturbance of the natural environment. In order to clarify Gray et al.'s (1995) position in relation to Laughlin's (1991), we will describe in the rest of this section inertia (no change) and two change pathways within each order of change. Some examples related to ecological crisis and environmental accounting are used in order to illustrate them.

\section{Inertia}

Laughlin (1991) theorizes that inertia is produced in those organizations that successfully avoid the environmental disturbance. In the case of natural environmental disturbance, inertia shows that the environmental agenda has been ignored by businesses and, consequently, that both environmental management systems and environmental reporting demands or requirements have also been ignored (Gray et al., 1995). Inertia in (conventional) accounting reveals its inability to handle that part of the ecosystem that as free goods does not acquire market costs (Gray, 1990; Birkin, 1996). One can see an example in the consideration of $\mathrm{CO}_{2}$ emissions by Spanish electrical utilities. The rate of $\mathrm{CO}_{2}$ accumulation in the atmosphere, the highest in the last 150,000 years, has brought the most important world leaders to sign the climatic change

Figure 1.

Equivalence between Laughlin's and Gray et al.'s models

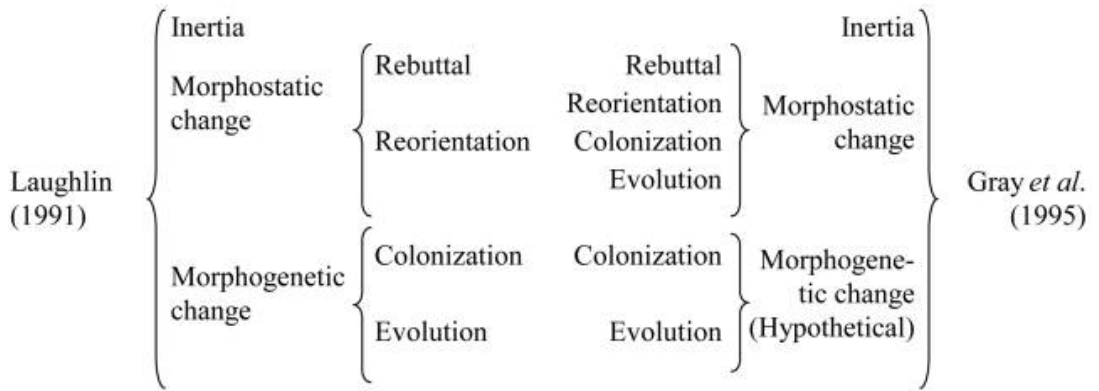


agreement in 1992 (Flavin, 1997). In this agreement they committed their countries to reduce emissions of $\mathrm{CO}_{2}$ to 1990 levels by the year 2000 (Flavin, 1997). In spite of this, the Spanish electrical utilities have ignored the importance of their $\mathrm{CO}_{2}$ emissions as much from the point of view of their management as in terms of environmental reporting (Larrinaga, 1995).

Rebuttal

Laughlin calls the first class of change morphostatic rebuttal, where the environmental disturbance induces limited changes that, primarily, affect the design archetypes but do not challenge the basic equilibrium of the organization based on an unchanged interpretive scheme. Within the sphere of the natural environment (Gray et al., 1995) this change pathway could be identified by a view that "the environment has nothing to do with us" or "our company does not have an impact on the environment”.

\section{Reorientation}

If the situation is that the organization cannot reject an environmental disturbance, Laughlin (1991) maintains that not only design archetypes, but also sub-systems will be transformed in some manner. This change pathway, called morphostatic reorientation, does not affect the basic coherence of the organization. Gray et al. (1995) who identified companies that had adopted environmental initiatives (corrective actions, investments and information disclosure) corroborates this. However, their explicit purpose was to reinforce the equilibrium of the company, based on conventional business concerns (financial savings, marketing, public relations, long-term survival and competitive advantage). This is consistent with the fact that the company uses environmental (accounting) information to improve its public relations (for evidence of this use, see Deegan and Rankin (1996) or Moneva and Llena (1996)).

Coming back to the Climatic Change Agreement, global $\mathrm{CO}_{2}$ emissions increased by 113 million tonnes in 1995, to almost 6,000 million tonnes a year. Even worse than that, the International Energy Agency anticipates that for the year 2010 global emissions will be 49 per cent higher than those in 1990 . Changes have only taken place at the level of signing agreements, while current patterns of resource consumption are being maintained and many rich countries are not fulfilling their 1992 commitments (Flavin, 1997).

\section{Colonization}

The third class of change identified by Laughlin, colonization, involves a second-order change, that is, it affects the core of the organization (interpretive schemes). However, it is characterized by the fact that it is a non-elected situation. Laughlin (1991) proposes that this kind of change is promoted by a group within the organization that imposes fundamental changes in both the visible and the invisible elements of the organization, forcing other members either to leave or to accept a new organization. It is worth mentioning that, in colonization, the shifts in the design archetypes force changes in the
Environmental accounting in Spain 
AAAJ

14,2

218

interpretive schemes and, therefore, this class of change may have destructive or regressive consequences caused by the contradictions between new design archetypes and the previous interpretive schemes (Laughlin, 1991). However, after surveying organizational responses to the ecological disturbance, Gray et al. (1995) found views that could be identified with colonization (and evolution), but could not detect adjustments within the interpretive schemes. This led them to theorize that colonization (and evolution) can be either morphostatic or morphogenetic (see Figure 1). Subsequently, they studied only morphostatic colonization.

Whereas morphogenetic colonization could not be found by Gray et al. (1995) in relation to this particular disturbance, they attribute the same motivation to morphostatic colonization as Laughlin (1991) did to morphogenetic colonization: the fear of the consequences of the environmental disturbance, that leads a company to act defensively. As a consequence of this, instead of bringing transparency into prominence, the organization tries to control and direct the change. It is therefore likely that accounting will be used to negotiate and define the concept of the environment (Gray et al., 1995).

\section{Evolution}

Finally, Laughlin's last type of change, morphogenetic evolution, implies changes in all the organizational components. However, unlike colonization the transformation is initiated by the interpretive schemes and characterized by a consensus of all its members that is reached through an open dialogue that facilitates a new common vision of the organization that is deliberately accepted. However, Gray et al. (1995) do not identify the presence of a discursive dialogue - as proposed by Laughlin for the evolutionary change but simply the opening of new forms of discourse and the questioning of some central myths pertaining to the organization that certainly cannot be compared with the shift of the interpretive scheme. Therefore, this path of change is labeled as morphostatic evolution (see Figure 1).

Although it is attractive to think of inertia and the rest of the change pathways in terms of a continuum, this notion should be avoided. As Greenwood and Hinings (1988, p. 303) put forward, "not all organizations pass through transitions or the same set of stages, nor do they depart from similar positions or have common destinations".

The relevance of the use of these ideas about organizational change is that the existence of environmental accounting could be either the sign of an evolution of business towards more environmentally friendly forms, or an instrument of environmental reorientation/colonization, leading to, or enabling, a process of capturing the environmental debate by regressive (conventional business oriented) interpretive schemes. In support of the first thesis it is argued that environmental accounting could strengthen new accountability relationships, providing visibility to the employment - or wasting - of the natural environment. However, if the second proposition better describes the reality, then environmental accounting could cause the most substantial 
aspects of the relationship between humanity and the environment to be forgotten (Puxty, 1986; Power, 1991; Tinker et al., 1991; Cooper, 1992).

Gray et al. (1995) adjust Laughlin's (1991) model, denying the existence of morphogenesis, and concluding that environmental accounting is being used to control and limit the environmental disturbance. Greenwood and Hinings (1988) suggest that "it is only from attempts to map tracks in different institutional settings that a richer understanding of organizational evolution and transformation will occur" (p. 310). In the following sections we will explore the change patterns adopted by some Spanish companies and discuss Gray et al.'s theory and conclusions.

\section{Research method}

In order to investigate whether Gray et al.'s theory applies to a different context, we have analyzed nine Spanish firms located in different industries and with different a priori attitudes to the environmental issue. Six companies out of nine were selected among those that replied to a previous postal questionnaire. Three more companies were added with the aim of giving a more complete picture of different attitudes and different industries, including the services industry (a brief description of each case is offered in the Appendix).

It could be argued that, for studying organizational change it would be more appropriate to carry out a longitudinal study. However, theoretical replication across cases (Yin, 1994) allows us to observe companies in different possibilities of change (Greenwood and Hinings, 1988; Laughlin, 1991; Gray et al., 1995). The replication logic must be distinguished from the sampling logic commonly used in surveys (Yin, 1994). For the number of theoretical replications, the important consideration is not whether the sample "represents" other cases, but to identify cases that should turn out differently as predicted by theory. Two main change orders are proposed in the theoretical framework. Thus, we selected four companies (A, B, F and I) that were expected to be located in morphostasis, and five companies (C, D, E, G and $\mathrm{H}$ ) that were expected to be morphogenetically changing (see Table I).

Data collection was based on a total of 15 semi-structured interviews, as well as on a search for relevant documentation in each case.

According to Laughlin (1991), it is the interpretive schemes (language and discourse), that provide coherence in an organization. Further, it is the

Ex ante classification

Ex post classification

$\begin{array}{ccll}\text { Inertia rebuttal or reorientation } & \mathrm{A}, \mathrm{B}, \mathrm{F} \text { and I } & \text { Inertia } & \\ & & \begin{array}{l}\text { Rebuttal } \\ \text { Reorientation }\end{array} & \mathrm{A}, \mathrm{B}, \mathrm{F}, \mathrm{I} \text { and C } \\ \begin{array}{ccc}\text { Morphostatic colonization or } \\ \text { evolution }\end{array} & \mathrm{C}, \mathrm{D}, \mathrm{E}, \mathrm{G} & \begin{array}{l}\text { Morphostatic colonization } \\ \text { and H }\end{array} & \begin{array}{l}\text { Morphostatic evolution } \\ \text { D H and G? }\end{array}\end{array}$

Environmental accounting in Spain

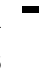


AAAJ

14,2

220

transition of this particular element that causes true organizational change. Individuals are not external to these discourses; they are passive transmitters of them, as well as active constructors. It is only through communication that we could acquire these corporate discourses. Therefore, we chose semistructured interviews (Ortí, 1986) as the main method for data collection. On the other hand, we were not only interested in the structured component of the discourse (objectified reality, see Berger and Luckmann, 1966). The unstructured parts (such as idealistic viewpoints) are likely to provide us with more information about the potential for transition, especially in those cases where the new balance and coherence has not been reached, and the company is in a schizoid position (Greenwood and Hinings, 1988; Laughlin, 1991). In-depth research methods, such as semi-structured interviews, could give us an insight into managers' apprehensions and motivations, after their perception of the environmental disturbance, and so acquire the unstructured parts of the organizational discourse. Semi-structured interviews were also used in Gray et al. (1995).

Though we initially scheduled two interviews in each organization, in three companies (A, D and G) we could only carry out one. In the remaining six companies, we accomplished an interview with a corporate environmental officer or a senior executive and another interview with someone closer to environmental or operations management. In spite of the fact that at best we only interviewed two individuals per organization, the collected opinions give us an indication of the prevailing subjectivity of the entire organization (Berger and Luckmann, 1966). Moreover, semi-structured interviews are aimed at the reproduction of motivational discourses of a typical personality in a given social setting (Ortí, 1986).

Each interview was designed to develop around three topics: importance attached to the environment by the interviewees and by the company; environmental management systems; and disclosure of environmental information. The interviews were carried out in April and May 1997. They were recorded and then transcribed for analysis. Only in case $\mathrm{C}$ did the person responsible for environmental issues refuse to be recorded. We also considered all the additional information that could be collected through personal observation.

Finally, with a view to triangulating evidence, documentation for each case was collected (previous questionnaires, annual reports, search in BARATZ[1] database, environmental reports and information available on the Web).

The analysis of the evidence was carried out in three phases. First, preliminary documentation of each case was used to a priori identify the companies' pattern of change (see Table I). Secondly, after data collection was completed, two members of the research team analyzed all the evidence of each organization, in order to investigate whether they matched the theoretical model developed in section two, and produced an individual case report. Patton (1990) states that, where variations of cases are the main focus of the study, it is appropriate to write a case analysis using the data of each one, before doing 
cross-case analysis. This analysis was achieved following a theoretical replication logic, where multiple case studies produce contrasting results for predictable reasons (Yin, 1994). Thus, if our nine cases turned out as predicted by the theory, we would provide support to Gray et al.'s theory and conclusions. In order to overcome bias, analysis was carried out through analyst triangulation (Patton, 1990; Yin, 1994). It was designed in such a way that two members of the research team, always different from those that carried out the interviews, analyzed the data. Thirdly, in order to draw crosscase conclusions, the authors met and all the nine individual case reports were presented and discussed, following a theoretical replication design (Yin, 1994)[2].

\section{Patterns of organizational change}

We now turn to report the analysis of our fieldwork[3]. This section establishes a dialogue between the theories developed above and the revelations obtained in the case studies, in order to explore whether Gray et al.'s (1995) model and conclusions apply to Spanish organizations. More space is devoted to the discussion of facts and views identified with colonization and evolution, as these change pathways are more significant for exploring the role of environmental accounting in organizational change.

\section{A priori patterns of change}

The selection of companies that were expected to follow different patterns of change was needed for theoretical replication. In order to select them, we used several sources of preliminary evidence, including a previous postal questionnaire carried out by the authors (Carrasco et al., 1997), a search in BARATZ database, environmental and annual reports and personal communications. This process included several steps:

First, considering their answers to the questionnaire, four companies - A, B, $\mathrm{F}$ and I - were a priori classified as less progressive (inertia, rebuttal or reorientation). These companies showed little or no concern at all about environmental issues, ignored the existence of environmental management schemes and lacked any environmental initiative.

Secondly, taking into account the questionnaires, cases $\mathrm{C}$ and $\mathrm{H}$ were a priori classified in more progressive patterns of change. These companies were well aware of environmental issues, environmental management schemes and they had initiated several environmental management practices. In $\mathrm{H}$ this information was corroborated by means of some environmental and annual reports available and previous research conducted by one of the authors (Larrinaga, 1995).

Finally, cases D, E and G were also added. A search in BARATZ database revealed that D had certified to UNE 77-801[4] environmental management scheme and that $\mathrm{E}$ was in process of doing so. Additionally, this search revealed that $\mathrm{E}$ was required by the environmental agency to implement some environmental corrective actions. $\mathrm{G}$ was also included for two reasons. On the

Environmental accounting in Spain 
AAAJ

14,2

222

one hand, this company was installing new sewage treatment facilities and trying to persuade politicians to allow $G$ to charge for the subsequent costs[5]. On the other hand, $\mathrm{G}$ was a newly established organization, owned by local councils, that could have weak interpretive schemes. Laughlin (1991) suggests that this should facilitate morphogenesis.

It is likely that our results provide an optimistic picture of the reality, as six companies were selected from amongst the 10 per cent that replied to a previous survey and three further companies were selected for representing the most progressive possibilities of change. However, this article does not claim to provide a "representation" of other companies.

\section{Inertia}

Inertia is produced in those firms that ignore the environmental agenda, and, thus, avoid any kind of change. The attitudes revealed by the interviewees suggest that most companies have some consideration for the environment. The view that the environment does not affect their company at all was scarcely expressed, and thus seems to corroborate the conclusions obtained in other Spanish surveys (Carrasco and Larrinaga, 1995). And yet, ignorance of the environmental impact of the companies was apparent in the previous questionnaire, as well as when the researchers questioned the interviewee about environmental issues. For example, when the researchers asked the financial director of A what the company's environmental impacts were, he responded by commenting on the impact of environmental regulation on the company. He went on to say:

Don't forget that at present our products ... do not have much impact on the environment (...) The only thing that affects us is that pine tree outside the building (LAUGHS) They wanted to remove it, but I was opposed. In fact it drops twigs on the roof and we have had leaks, but, well, it is only a matter of cleaning the roof (A: financial director).

In the same vein, the case for the lack of pollution in Andalusia (Southern Spain), is explained by a financial institution's executive as being due to its industrial underdevelopment relative to the rest of Spain:

In Andalusia, unfortunately, there are so few companies, so few factories, ... that there is no direct impact on the environment (I: center director).

This opinion reveals an ignorance of the environmental reality of the region and perhaps an attitude of rebuttal toward the environmental issue. This view seems to be widely shared in Spain and was expressed one year before the ecological catastrophe caused by Los Frailes dam failure in Boliden's mines near Doñana, in Andalusia, in April 1998.

\section{Rebuttal}

A rejection of the organizational impact on the environment is the primary feature of the first change pathway. However, together with this consolidated view, we found that the executives develop an idealistic discourse, involving the description of an environmentally Utopian state of affairs that is in no way 
connected with their companies. As will be explained below, the existence, at different levels, of these two contrasting discourses results in rebuttal being a robust model for explaining the behavior of many companies.

There is evidence of an attitude of rebuttal in many of the firms: A, B, C, F and I (see Table I). In accordance with Gray et al. (1995), we found a structured discourse that tries to legitimize the firm's behavior. They do so in two main ways. On the one hand, in these companies there is strong evidence of the refusal to recognize the environmental impact of the company.

This company, actually, does not have much to do with the environment (B: administration director).

This isn't a company that makes fridges or sausages or beer, and it doesn't emit smoke, O.K.? (F: president).

This is a plant that is going to release few pollutants into the environment. It is a very hightech factory (C: personnel officer).

Though $\mathrm{C}$ was a priori classified in the more progressive change pathways, it surprisingly showed a strong rebuttal attitude.

On the other hand, as responsibility for environmental matters become more obvious, the discourse changes with a view to diverting responsibilities away from the company, and this, in turn, can be achieved through blaming several stakeholders: first, the environmental problems are attributed to the supplying manufacturers.

With PVC ... I believe that that is the manufacturers' problem (A: financial director).

These controls should have been undertaken by the manufacturers of the products that we only sell. Of course, we are required to ensure that the products meet certain standards, but it is the manufacturer that should control this more than us (B: administration director).

Secondly, interviewees argued that their companies are but the servants of consumers and react to their demands.

Up until now we have not had any trouble or rejection in the market with regard to PVC, on the contrary, demand increases more and more (A: financial director).

For an argument against this view, the European Commission approach (e.g. EMAS regulation)[7] recognizes the importance of companies being involved in the environmental issue, without waiting for market signs (see also Lindblom, 1984; Mouck, 1994).

Even so, the main party blamed by our interviewees was the Government and their voters.

I believe that the companies lack ability, autonomy, knowledge, determination (...). The initiative must come from the Government (I: center director).

They argued that people voted for a Government that allowed them to carry out their polluting activities, thus legitimating these activities. Consequently, they argued that if something has to change, the initiative must come from voters and Government, but not from the company. C's personnel officer explained that he presumed that the industrial park where $\mathrm{C}$ was based should

Environmental accounting in Spain 
AAAJ

14,2

224

be well designed from an environmental point of view, because the Government decided its location.

We are persuaded of this because it was so decided by the Government [that has been elected] by the Spanish people (C: personnel officer).

Finally, even the ecologists were blamed by the president of a Golf Club in the dry South of Spain.

How is it possible that ecologists came to be concerned about our company's water consumption [for watering the golf course]? They should go to argue their point with the local authorities, who haven't done anything about fixing their pipes so that water doesn't run away (F: president).

According to Sethi (1978; quoted in Näsi et al., 1997), legitimacy problems occur when a gap between social expectations for corporate behavior and society's perception of that behavior exists. This legitimacy gap is caused by the evolution of society's expectations as, we hypothesize, is the case for environmental disturbance. Sethi (1978; quoted in Näsi et al., 1997) suggests that there are four possible strategies in order to reduce a legitimacy gap. First, do not change performance, but public perception of performance. Second, if changes in public perception are not possible, change the symbols used to describe business performance. Third, attempt to change society's expectations of business performance. Finally, change business performance. In some respect, this theorization resembles the distinction between legitimacy theory and political economy theory (Buhr, 1998). Thus, the first and second strategies allude to the social constructionist view of legitimization, also called legitimacy theory, and the third strategy denotes the hegemonic perspective of legitimization, also called political economy theory. It seems that rebuttal and changing the public perception of performance are the simplest forms of legitimation.

Greenwood and Hinings (1988) argue that after losing one archetype coherence, and before reaching another archetype coherence, a schizoid incoherence "reflects the tension between two contradictory sets of ideas and values" (p. 304). At this level of change we discovered a double discourse that evidenced a contradiction between two sets of values. On the one hand, a structured discourse rejected any environmental impact of the company and helped to sustain the coherence of the unchanged organization. We have named it factual discourse. On the other hand, an unstructured idealistic discourse came out, based on the personal conscience of the executives.

I believe that it is a moral preoccupation for the common good (. . .) The environment is one factor, (. . .) we try to be good citizens (C: personnel officer).

But a conscience that was not applicable to the organization, as was frankly expressed to us:

We have a conscience, but it is not developed since [environmental issues] do not affect us. Of course, everybody is concerned, but when it has an effect on something, it is finished (B: financial director). 
This distinction between idealistic and factual discourses enriches the analysis, since it permits us to observe the dynamic nature of organizations and differentiate between change pathways (tracks for Greenwood and Hinings, 1988). Rebuttal (aborted excursions in Greenwood and Hinings' nomenclature) does not impose a passage through a schizoid incoherence. Our evidence reinforces this view, as the new set of idealistic values is not reflected in new elements in the organization.

\section{Reorientation}

Gray et al. (1995) contend that many companies would try to reject the environmental threat - as do companies in rebuttal - but they are not willing to be seen doing so. Therefore, in reorientation, organizations undertake a limited response that involves shifts in design archetypes and in sub-systems, but always with a view to reinforcing the basic coherence of the organization, without threatening the interpretive schemes. For example, $\mathrm{E}$ was in process of implementing environmental management systems and had to accomplish environmental investments.

The discourses that came to light in reorientation are consistent with Gray et al.'s (1995) results, as they are based upon economic efficiency, benefits, the achievement of competitive advantages, ecological marketing or, simply, the existence of the company. Factual and idealistic discourse can be also analyzed separately. Only in case E, a chemical company, is a structured real discourse on reorientation found. In other cases - A, B, C and I - unstructured idealistic viewpoints on reorientation were found. However, this fact has to be dealt with cautiously. These idealistic views express only personal concerns, but not the reality of what was taking place in the company. The following two quotes clearly state the difference between $\mathrm{E}$ (reorientation) and $\mathrm{B}$ (rebuttal).

The environment starts to be treated as a very important issue in large companies, just as five or six years ago occurred with quality management. It is not a matter of accepting the issue or not, as the very survival of the company depends upon the existence of verified management systems (E: production director).

They ought to require [companies] to implement the means to avoid environmental impacts. There ought to be a requirement for this (B: financial director).

Both quotes express concerns about the possibility that the environmental disturbance could jeopardize the future of their companies. However, the first quote manifests a real (factual) concern, while the second is just expressing personal (idealistic) thoughts. This difference between the quotes of $\mathrm{E}$ and $\mathrm{B}$ can be observed in relation to the remainder of the issues around which reorientation viewpoints are expressed.

A second important issue deals with economic efficiency and positive benefits (the environment pays), as well as in negative (the environment costs) terms. The environment costs because it can affect the organization's activities through fines, contingencies and the need for achieving environmental
Environmental accounting in Spain

225 
AAAJ

14,2

226

investments. While Gray et al. (1995) did not explicitly mention this negative aspect, our interviews highlighted its relationship to reorientation.

With respect to the environment, some activities and internal measures must be taken and this is a cost that must be borne (E: environmental controller).

On the other hand, as proposed by Gray et al. (1995), reorientation reveals a green marketing discourse, connecting environmental issues with positive benefits.

In advertising, we could take advantage of this. But always, of course, with a view to company's profitability (B: financial director).

The issue has emerged in our advertising. Well, our corporate image is a [protected animal]. It lends itself to this issue [using the protected animal for green marketing] (A: financial director).

It could be argued that reorientation is a more sophisticated manner of legitimation than rebuttal. The collected views suggest that there is some activity of changing the symbols that describe environmental performance (environmental management certification and green marketing), as propounded by Sethi (1978, quoted in Näsi et al., 1997) for his second strategy.

Once having analyzed the evidence of less progressive routes of change, we could recapitulate. Six (A, B, C, E, F, and I) out of nine companies should be undoubtedly located - given their discourses - in morphostasis (see Table I)[8]. Though we found cases of ignorance - identified with inertia - most of the interviewees recognized the significance of environmental matters. The dominant discourse in these organizations tried to rebut the environmental disturbance by means of a "the environment has nothing to do with me" stance. This is reflected in very limited changes in the organization. On the other hand, the fact that only $\mathrm{E}$ was changing in accordance with morphostatic reorientation could be explained because in the chemical industry the environmental disturbance cannot be successfully rejected.

\section{Colonization}

In those organizations that were undertaking generalized changes as a consequence of ecological disturbance, Gray et al. (1995) found a significant strategy of skirting the issue. Consequently, in their opinion, it would not have a great impact on the core of the organization. On the contrary, the companies they analyzed attempted to limit the impact, taking the initiative and seeking to define (to construct) their own environmental disturbance, guided by the dominant rationales of business. Therefore, it is difficult to conceive a morphogenetic change and, accordingly, colonization is morphostatic.

The changes and motivations of colonization are analyzed next. In our study, two companies - cases $\mathrm{D}$ and $\mathrm{H}$ - were experiencing generalized changes in both sub-systems and design archetypes. The analysis of documentation and interviews revealed that these companies had borne changes in sub-systems: productive processes were modified; current 
technology was questioned to a limited extent; and, more importantly, the behavior standards of the organization's members changed:

We have seen that, in fact, when you act respectfully, thoughtfully, with the adequate technologies to avoid (...) It is not avoidance, it is reducing the environmental impact of industrial facilities (...) There are always modifications, but they tend to be small. And those modifications relate rather to modifications in individuals' behavior. That is to say, if instead of forcing people to do something, you explain them the why, then, it leads individuals to say: "hell, this is the time to act". So they will help you telling where a container should be placed for materials recycling ( $\mathrm{D}$ : environmental director).

The analysis of documents (news in the press, one environmental report from $\mathrm{D}$ and several environmental publications from $\mathrm{H}$ ) and interviews revealed that $\mathrm{D}$ and $\mathrm{H}$ were also undertaking modifications in design archetypes. In $\mathrm{H}$ there was an officer in charge of environmental management, and an operational department was devoted to the issue. The environmental officer was accountable to the board, and produced an environmental report. There were also on-line control systems of emissions. And the environment penetrated many of the information systems (budgets, intranet, management control). Likewise, in D there was an officer responsible for environmental issues and an environmental committee that brought together all those people responsible for the functions involved. Systematic records were kept, employees were informed through the health and safety committee meetings, and an environmental report was also produced. Both companies implemented UNE 77-801 environmental management system.

While the previous evidence denotes important changes at the level of subsystems and design archetypes, we will next consider interviewees' attitudes in order to appreciate whether interpretive schemes are affected or not. The motivations to colonize the environmental disturbance derive from the environmental threat. If there is a word that could define this type of change, this is fear (Gray et al., 1995). Fear of fines, of criticism or of losing markets. However, this fear is not paralyzing. The company, against its own will, develops a proactive attitude toward the environment that could be synthesized by the minimization of their own risk. To this effect, we consider very enlightening the taxonomy of different pressures, given to us by H's environmental controller. He distinguished between compulsory and noncompulsory pressures. Gray et al. (1995) offer a similar classification, except that what to our controller are compulsory pressures, to Gray et al. are indirect business reasons: "a fear of prosecution, a fear of exposure to public criticism, a fear of accidents" (p. 226). And what the interviewee considers to be noncompulsory pressures, is considered to be direct business reasons by Gray et al. (e.g. public relations or financial savings). Clearly, H's environmental controller is more concerned by regulation than Gray et al. (1995) are. In the view of our controller, compulsory pressures come from compliance with pollution abatement regulations, the pressures received from ecologists, society, etc.
Environmental accounting in Spain

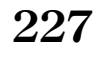


AAAJ

14,2

228
As the pressures begin to squeeze you all over, or pushing you from behind, and even though you want to defend yourself, they carry you forward. They are compulsory: the law, the society, the ecologists (H: environmental controller).

Regulation is affecting the companies tremendously, because whether we want them or not, Spain has accepted some commitments with the European Union. And among those commitments is the implementation of all the environmental regulations that existed before in Europe (...) and they have very dramatic consequences for companies (D: environmental director).

Even though ecologists are frequently identified as large change drivers for companies (e.g. the case of Shell; see Barbone, 1996), in our interviews we only found some indirect references. And unsurprisingly, when ecologists are perceived to be important, they are compared to regulators. It seems that ecologists are perceived to drive regulation, and the enforcement of regulation, especially by those companies that have seriously considered environmental issues.

Greenpeace reports must be considered as seriously as a Government report ( $\mathrm{H}$ : environmental controller).

A final source of compulsory pressure is the executive's personal risk. The need for controlling the environmental risk is particularly apparent in case $\mathrm{H}$, where it is considered that non-compliance with regulation signifies a direct risk for the members of the board, i.e. the executives' risk of going to jail after a lawsuit for environmental offences.

That is to say, if I was a factory director, I would be interested in the issue. Not perhaps because of market share (. . .) But because I could sleep at night if I know that no one is going to call me saying that the police came because we released a toxic substance $(\mathrm{H}$ : environmental controller).

In fact, the interest in the environment emerged in case $\mathrm{H}$ because the president of another important company in the industry was charged with ecological offences, and, subsequently, $\mathrm{H}$ designed environmental management systems and responsibilities.

The president of the company was led to the witness stand charged with ecological offences! (...). [Subsequently, in our company] board reports were issued asking what was going on (...) Despite the fact that environmental issues might be controlled from the shop floor, the one who is taken into the witness stand is the president of the company. If we have a person in charge, it is he who has to face up to the consequences (...) (H: environmental controller).

Turning to non-compulsory pressures, we found similarities with the motivations manifested by companies that were placed in reorientation. The main difference lies in that in colonization the environment is perceived as a real threat - connected with the central motivation of this type of change: fear. This threat derives from a greater awareness and a better conceptualization of the implications of change than in the case of reorientation.

In addition, the big changes have been brought about by non-compulsory [pressures], that is to say, the view that environmental issues can be an opportunity for the company. I climb on 
the bandwagon, not because I'd go to jail or because I am going to have to pay fines, but because I realize that this can be good for business (H: environmental controller).

The sources of non-compulsory pressures are diverse. First, the customers:

We had some important customers that were trying to persuade their suppliers to be environmentally certified (...) It's true, we have had pressure from clients (...) It is a chain reaction, and it works (D: environmental director).

In case $\mathrm{D}$, a manufacturing company, selling to a few industrial customers, green marketing is severely criticized. Could it be because they cannot use green marketing? The views expressed by the environmental director of $\mathrm{D}$ suggest that they would use it, if they could:

Those companies that sell directly to the public are taking advantage of green marketing. Logically, we cannot do the same and neither can any other company in this industry (. . .) On the other hand, you will agree with me that green marketing is a tall story (D: environmental director).

A second source of non-compulsory pressure comes from the stakeholders that manage financial risk: insurance companies. This is apparent in the account of the experience of an electricity company:

The first environmental audit carried out in [work center] astonished us. An insurance broker carried it out. The insurance policy said: "before fixing a premium we want to know what's going on, tell us whether you have PCBs[9] or fire extinguishing systems". They came, saw what was going on and the premium was fixed (H: environmental controller).

A third non-compulsory pressure is specific to countries that are lagging behind on environmental issues. The pressure comes not just from international competitors, but also from the parent company, as is apparent in case D.

[Our parent company] is a [Swiss] multinational. So they have taken the issue seriously, because, as you know, the level of conscience there is different to the rest of Europe (...). They wanted all their subsidiaries to implement environmental management systems (...) Therefore we began in 1993 (D: environmental director).

Finally, with respect to workers and unions, these companies have a great interest in their participation, but it does not appear to be a major motivation for change. We could not find any reference to workers or unions as being environmental change drivers[10].

The constant allusion to fear, as well as the above-mentioned classification of pressures, reinforces the qualification of $\mathrm{D}$ and $\mathrm{H}$ as colonizing change. Particularly, if we analyze what is said by the environmental controller of $\mathrm{H}$, he mentions "pressures", but not "motivations" (as do Gray et al., 1995). The fact that change is driven by fear is reinforced by the use of the "compulsory" - or "non-compulsory"-adjective.

One characteristic of colonization is that change is forced upon the organization (Gray et al., 1995; Laughlin, 1991). It is worth mentioning that while Laughlin anticipates some negative, unexpected or destructive effects of this type of change (note that Laughlin conceives colonization as
Environmental accounting in Spain 
AAAJ

14,2

230

morphogenetic), Gray et al. are much more cautious as a consequence of their reconsideration of this change as morphostatic. They consider that interpretive schemes, such as the values and the unquestionable objectives of business, are safeguarded. Its central myths such as short-term benefit, growth, and secrecy continue to play their role. The analysis of our interviews provides more evidence on the fact that colonization of the environment does not entail shifts in the values of the organizations.

Though $\mathrm{C}$ and $\mathrm{E}$ were a priori classified in the more progressive change pathways, we could not identify general changes at the level of sub-systems and design archetypes. Thus, we interpret that they follow rebuttal and reorientation changes. This error could be explained because both cases were subsidiaries, and most of the evidence considered a priori were referred to the parent company. For example, environmental reports from $\mathrm{C}$ and $\mathrm{E}$ were in fact issued by their parent companies. Even though these cases did not turn out as foreseen, we could not find internal contradictions. In this respect, the error is to be attributed to the interference of parent companies (that should be considered an external pressure, as discussed previously), rather than to the theoretical model.

\section{Evolution}

The more proactive pattern of change identified by Laughlin (1991), evolution, is called morphostatic evolution by Gray et al. (1995), because they could not find any "Real adjustment of the priorities of the organization away from a business-centered, rather than environmental-centered point of view" (Gray et al., 1995, p. 226).

These authors find at best two characteristics of morphostatic evolution: the company starts to question its central myths and it is open to new discursive forms both within the company, and between the company and its shareholders. The unchanged interpretive schemes and the emergent discourses will be analyzed consecutively.

To begin with the unchanged interpretive schemes, central values of the conventional business view - short-term benefits, secrecy and business growth - are not questioned, even in the most advanced organizations. Secrecy will be further analyzed in section 5, as it is central for our research aim. The discussion of short-term benefit and business growth follows. On the one hand, it must be remembered that companies are created to earn money:

Companies are created to earn money. Therefore, anything that contributes to short to medium-term profits is fine. But it has still not been proved that environmental steps are going to bring about profits (D: environmental director)

Environmental issues are considered to be more important when they have an economic influence (...) And then, when they affect human health (H: environmental controller).

On the other hand, the most important objective of businesses is growth. In their opinion, environmental degradation is not going to stop the expansion of traditional companies, since: 
The companies are much more concerned (...) and, despite this, the sales volume and the business figures have been increasing and new companies have started up in this area $(\mathrm{H}$ : environmental controller).

Finally, it is difficult to classify case G. We identified in this company the opening of new discourses and the questioning of some myths, not only with respect to the compatibility between growth and sustainability, but also in relation to transparency and responsibility.

There is an incitement to over-consumption, and almost nobody is willing to give up (...) Everybody speaks about sustainable development and so on, but I can not see how it relates to the economic activity (G: president).

The more information about this, the better (...). We believe that it will be necessary to launch an information campaign for the older people to justify to them what they pay and so on (...). And to the younger people because they are very concerned (...) as it is their own lives and the lives of future generations that is at stake (G: president).

These views suggest that organizations with weak interpretive schemes are more likely to experience evolution, or even morphogenesis, as pointed out by Laughlin (1991).

Summarizing colonization and evolution, those companies that are assuming generalized changes in both sub-systems and design archetypes, are mainly motivated by a fear of the consequences of environmental disturbance. On the other hand, interpretive schemes remain untouched from the environmental point of view, as Gray et al. (1995) propose. Finally, the argument that organizations with weak interpretive schemes could reach morphogenesis more easily is supported by the responses in case $\mathrm{G}$.

\section{The role of environmental accounting in organizational change with respect to the environment}

This section continues the analysis of the fieldwork, focusing on the role of environmental accounting. Since our results suggest that morphogenesis is not taking place, it follows that neither environmental accounting nor any other element is generating any significant organizational change in the consideration of the biosphere. Nevertheless, in a few cases there is some kind of potential for morphogenesis. If we look at the quantity of modifications that are being generated at the level of design archetypes in some firms, even though interpretive schemes are not substantially affected, one would believe that internal contradictions could provoke a potential for morphogenesis. To play any significant role at all in morphogenesis, environmental accounting should be coupled with the attribute of organizational transparency, "a window into the organization" (Gray et al., 1995, p. 231) that could empower stakeholders and, strengthening the disturbance, stimulate business change.

Setting aside inertia, we found some environmental reporting activity in organizations that have shown rebuttal $(\mathrm{C})$, reorientation $(\mathrm{E})$ and colonization $(\mathrm{D}$ and $\mathrm{H})$ models of change. Disclosure of environmental issues amounted to a page in the annual report of C's parent company. It also published a sporadic environmental report of 33 pages, in Spanish, providing large pictures and
Environmental accounting in Spain 
AAAJ

14,2

232

some information on the products. This report did not provide any information about C's environmental impact. Moreover, although C expressed to us their aim not to conceal anything, the environmental controller did not allow us to record the interview; neither did he provide us with a copy of their plant emission records.

On the other hand, while $\mathrm{E}$ was preparing an environmental report for the first time, its parent company does publish a report periodically.

I am finishing a report for [the parent company] on the environment for the year 96, and it has about 16 pages and 9 pictures of natural sites (E: environmental protection coordinator).

Reorientation is featured by the use of information intended for public relations and that does not relate to the organization's situation. It is very unlikely that this form of environmental accounting could help to increase transparency and to build corporate accountability (Gray, 1997). The environmental protection coordinator of $\mathrm{E}$ states that environmental information disclosure has many advantages. However, and significantly, he told us that he could not give us the same information if we recorded the interview. Furthermore, later on environmental information turns out to be not so good:

Information can be manipulated, misinterpreted (. . .) For skilful people it could be valid, but for others it could turn out to be a destructive weapon. [Because of this] it is easy to criticize and to pillory someone for any reason (E: environmental protection coordinator).

E's limited commitment to transparency is, finally, evidenced by the use of the expression "to make publicly available" as an excuse not to publish environmental information (see below).

Legitimacy theory explains environmental accounting in cases $\mathrm{C}$ and $\mathrm{E}$, because, on the one hand, they are reacting to the environmental agenda (although in different ways) and, on the other hand, they are trying to divert attention away from their pollution records.

D produces an environmental report, as a necessary part of the requirements to obtain its environmental certification by the UNE 77-801 standard. Note that UNE 77-801 required companies to make an environmental report publicly available, while EMAS requires that this environmental report be disclosed and spread amongst interested parties. In cases D and $\mathrm{E}$, the expression "to make publicly available" was used as an excuse not to publish the environmental report. Resistance to disclose environmental information is indicative of their secretive attitude vis-à-vis the environmental issue.

We must display them [environmental reports]. They are publicly available. However, to make publicly available does not mean to publish them. Ha, Ha (...). One must take a lot of care with the information that is released (...) We sell to few clients, so to publish it is like throwing money away because people browse and think "so what?" We do make it publicly available. We have obviously sent our environmental report to our customers, and it has been put on the notice board so that everybody can see it (D: environmental director).

We did obtain D's environmental report, but only once the environmental director had consulted with the CEO. Their environmental report is quite mature: it presents an eco-balance, with relevant environmental records, as well 
as standards for the next year; records are adjusted by scale; compliance with standards percentages is also presented (92 per cent). But, in spite of its sophistication, the report remains unpublished.

The last company analyzed here $(\mathrm{H})$ seems to have a greater determination with regard to transparency. An environmental report of the main power station is published annually. Furthermore, in the annual report several pages are published annually, including ecological motive photographs, the corporate environmental policy statement, information about centers certified to environmental management schemes, and environmental performance records (quantitative emission records of $\mathrm{SO}_{2}$ and particles). Company $\mathrm{H}$ has also undertaken several initiatives to integrate in its local environment, through the programming of open days intended for students, local associations, etc.

Furthermore, interviews in $\mathrm{H}$ evidenced a new discourse that focused on communication with the society and transparency.

I think that [companies] must communicate a balance between the benefit that companies yield and the environmental costs (H: environmental controller).

If you have an environmental conscience and you are not transparent, then forget it. (...), we think that transparency is good (...) Because the traditional secrecy that existed in the industry has been shown today to be very prejudicial. People are afraid of industry, because they don't know it (H: environmental responsible).

Reinforcing the transparency discourse, interviewees do not conceal that H's activity of electricity generation is highly polluting.

We have all kinds of possible impacts, because we have many facilities, each one with its own characteristics and very different environmental impacts ( $\mathrm{H}$ : environmental controller).

Secrecy in the less proactive patterns of change is not surprising. In the same vein, we should foresee that a company experiencing a morphostatic colonization change will not relinquish this value. Indeed, in case D, a highly developed knowledge of environmental accounting is coupled with a resistance to the arguments that support transparency (e.g. the above-mentioned requirement of making information publicly available). However, what does seem more interesting is the opening of new discourses in $\mathrm{H}$, as was discussed in the last section.

In fact, $\mathrm{D}$ and $\mathrm{H}$ are using environmental accounting proactively with a view to setting the agenda and maintaining control. That means, not only producing creative accounts, but also persuading shareholders that this information interests them.

[Environmental reporting] provokes misunderstandings, because everyone produces records... This is not regulated. That is to say, you produce the records as you want, in your interests (D: environmental director).

[Environmental reporting is useful for] the Environmental Agency, universities, those affected by the company's environmental impacts, ecologists, though I understand that they still receive it with distrust. And it should concern shareholders very much. But I understand that they are still not sufficiently concerned. However, those who risk more money on the company, a bank for example, or a main shareholder, are already interested. And nowadays
Environmental accounting in Spain 
AAAJ

14,2

234 among the risks to the company there is the environmental one (...). Our plan is to send [the environmental report] to all the shareholders (H: environmental controller).

This process would allow the most proactive organizations to build the scope of the environmental disturbance. It emerged from the interviews that environmental accounting provides a window out of the organization (Gray et al., 1995), a way of changing society's expectations about corporate environmental performance (Sethi, 1978, cited in Näsi et al., 1977). Environmental accounting seems to be used by colonization organizations to take the lead on the environmental agenda with the aim of limiting and controlling the influence that the environment would have on the company. In terms of political economy theory (Buhr, 1998), they try to maintain control. Indeed, the environmental controller of $\mathrm{H}$ is annoyed because environmental accounting has not been fully successful in this role.

Up until now we have not had anything that had turned against us. (...) Instead we have found disappointment in the sense that [environmental reports] have not produced the desired effects [in other companies]. Or even we have found the total indifference amongst the public (...) The worst scenario would be that [environmental information] be taken by an ecologist group, and they run you down because you are not complying or you are lying $(\mathrm{H}$ : environmental controller).

This gives rise to a complex situation, where they try to manage truth, to avoid the undesired use of information and to construct a public environmental agenda. Interestingly, H's environmental controller thinks that this project is successful to some extent.

To the ecologists' dismay and unfortunately for them, the big companies, their traditional enemies, have climbed first onto the bandwagon and who now wave the largest environmental flags (H: environmental controller).

This analysis illustrates the tension between the two explanations provided in the introduction. On the one hand, environmental reports could provide stakeholders with a window to the organization, promoting visibility and transparency. On the other hand, it also could provide a window of the company to society, promoting the entrepreneurial control of changes that are taking place outside. In the most proactive organizations identified, controlling the scope of the environmental disturbance and constructing public perception of corporate environmental performance, take precedence over transparency.

Obviously, from an environmentalist viewpoint, the undesired effect of the companies involved in this process is that while they are the main contributors to the ecological problems, they are starting to set the ecological agenda. Therefore, it seems likely that they would focus on what does not jeopardize them (e.g. end-of pipe solutions) and would avoid new designs and organizations demanded by the ecological problems.

Though Adams and Kausirikun (2000) argue that, in the case of Germany, accounting values, as theorized by Gray (1988), do not explain environmental accounting practice, we have found that companies placed in colonization are those who develop a higher environmental reporting activity for the mentioned 
reasons. The anomaly identified by Adams and Kausirikun (2000) could be explained by the diverse uses of environmental accounting in organizational change. Indeed, it seems that those companies who feel the higher environmental disturbance (as is hypothesized by these authors for Germany) try to colonize the environmental agenda by means of environmental reporting.

\section{Conclusions}

We have studied the relationship between environmental accounting and organizational change, in the Spanish context, using Gray et al.'s (1995) and Laughlin's (1991) models. Through the paper we have described the discourses that emerge in different organizations and outlined a map of organizational change for the nine firms that we studied. In six out of the nine companies, either rebuttal or reorientation viewpoints were found. Conversely, cases D and $\mathrm{H}$ showed colonization discourses. Changes in the later organizations were driven by fear, as suggested by Gray et al. (1995). In spite of the fact that we identified in case $\mathrm{H}$ the opening of new viewpoints and the questioning of conventional business values that Gray et al.'s (1995) identified as evolution, this company has to be placed in colonization, given its motives for change. It also emerged from the study that colonization and evolution does not imply morphogenesis, as the emergent idealistic discourses do not impinge substantially in the organizations and their central values remain unchanged. It should be concluded that Gray et al. (1995) explanation of different patterns of organizational change as a reaction to the environmental disturbance is a useful tool for interpreting this fieldwork.

Most organizations in our survey develop a multidimensional discourse that we have tried to break down into, on the one hand, factual discourse, and, on the other hand, an emergent idealistic discourse. These two complementary discourses allow us to discriminate between the dominant attribute (factual) of each interview and the temporarily discarded one (idealistic). For instance, the transparency discourse is complementary to the factual discourse of fear, permitting $\mathrm{H}$ to show at the same time, though at a different level, characteristics of colonization and evolution. The distinction between factual and idealistic discourses is also useful for separating different tracks. For example, while the viewpoint of fear is present in rebuttal and reorientation at an idealistic level, so it is in colonization at a factual level.

Considering the main objective of the research, critiques of the theorization of environmental accounting, as a way of strengthening an environmentalist viewpoint of the organization, are supported by the research reported here. The more progressive organizations, those that generally disclose the biggest amount of environmental information, use it actively to mold the scope of the environmental disturbance and the perception of corporate environmental performance. It is very unlikely that, used in this way, environmental accounting could have any significant impact on organizational change.

Strengthening this point, secrecy is one of the accounting values in Spain, as regards not only financial accounting, but also environmental accounting. The
Environmental accounting in Spain 
AAAJ

14,2

236 reported resistance to transparency constitutes a serious obstacle for environmental accounting. Furthermore, what is more intriguing is that the companies where new discourses of transparency are emerging, are those that are attempting to control and negotiate the environmental agenda. This Spanish evidence corroborates Gray et al.'s (1995) conclusion that any form of environmental accounting will involve a trade-off between transparency and control of the environmental agenda. Inevitably, from an environmentalist standpoint this is a paramount objection to environmental accounting. It is unlikely that the richness of the biosphere could be acknowledged from a business-centered point of view.

However, while environmental accounting is currently being used so as to limit the issue, the fact that transparency has emerged in the discourse of some organization's actors, could be seen optimistically as the sign of a potential archetypal incoherence (Greenwood and Hinings, 1988). Archetypal incoherence would suggest some potentiality of transition to a higher order of change. This incoherence mirrors the complexity of environmental accounting, which could make the debate around legitimacy and political economy theories sterile. Indeed, this study elucidates that elements of both theories are present, though at different levels, to explain the activity of environmental accounting.

Whether the potential positive aspects of environmental accounting outweigh its present objections is something that needs further research. But, certainly, the present practice of environmental reporting must be critically examined.

\section{Notes}

1. BARATZ database includes all articles on economic, social and political issues published by 33 Spanish periodicals and journals.

2. Interviews and analyses were carried out in the Spanish language. Quotes from the interviews are translated as accurately as possible. However, in some instances, in order to enhance understanding, some interpretations were needed.

3. This means that we are not presenting the whole analysis, but some examples of the facts and views that persuaded us to match the cases with the theory.

4. This standard, called "Sistema de Gestión Medioambiental", was issued by AENOR (Spanish Association for Standardization and Certification). It was later substituted by ISO 14001.

5. This information was obtained through previous personal communication, between one of the authors and the president of the organization.

6. Moreover, Andalusia concentrates 12 per cent of Spanish firms affected by the IPPC regulation (Expansión, 1998; Integrated Pollution Prevention and Control Directive of the European Communities, 96/61/EC). Also, the only Spanish disposal site for nuclear waste is located in this region. The case of the relative gap between Spain and the rest of Europe seems to have been successfully used by Spanish regulators as they have achieved less stringent objectives in $\mathrm{CO}_{2}$ reduction in the European Commission negotiations.

7. Eco-Management and Audit Scheme. European Commission Regulation, in which industries can voluntarily participate, implementing an environmental management system that includes the issuing of an environmental report, and the external verification of the whole system. 
8. Companies $\mathrm{C}$ and $\mathrm{E}$ were located $e x$ ante in more progressive patterns of change. Alterations in the ex post classification are due to the inability of identifying public relation exercises in postal questionnaires and corporate reports. Semi-structured interviews allowed us to better appreciate motivations.

9. PCBs are mixtures of synthetic organic chemicals. Due to their non-flammability, chemical stability, high boiling point and electrical insulating proprierties, PCBs were used in hundreds of industrial and commercial applications, including electrical equipment (see http://www.epa.gov/opptintr/pcb/index.html). PCBs are carcinogenic and legislation has enforced the cessation of its use in many countries.

10. Rather, Spanish unions have supported blamed companies after ecological disasters (Doñana) or offences (Puignero case), demanding reopening the factories (see Páez, forthcoming).

\section{References}

Adams, C. and Kausirikun, N. (2000), "A comparative analysis of corporate reporting on ethical issues by UK and German chemical and pharmaceutical companies", Eurobean Accounting Review, Vol. 9 No. 1, pp. 53-79.

Barbone, C. (1996), "The battle for Brent Spar", Communication World, Vol. 13 No.1, pp. 27-30.

Bebbington, J., Gray, R. and Owen, D. (1999), "Seeing the wood for the trees. Taking the pulse of social and environmental accounting", Accounting. Auditing and Accountability Journal, Vol. 12 No. 1, pp. 47-51.

Bebbington, J., Gray, R., Thomson, I. and Walters, D. (1994), “Accountants' attitudes and environmental-sensitive accounting”, Accounting and Business Research, Vol. 24 No. 94, pp. 109-20.

Berger, P. and Luckmann, T. (1966), The Social Construction of Reality, Spanish translation: La Construcción Social de la Realidad, Amorrortu Editores, Buenos Aires.

Birkin, F. (1996), “The ecological accountant: from the cogito to thinking like a mountain”, Critical Perspectives on Accounting, Vol. 7 No. 3, pp. 231-57.

Buhr, N. (1998), "Environmental performance, legislation and annual report disclosure: the case of acid rain and Falconbridge", Accounting. Auditing \& Accountability Iournal, Vol. 11 No. 2, pp. $163-90$.

Carrasco, F. and Larrinaga, C. (1995), "Organizaciones, contabilidad y el entorno natural”, Revista Española de Financiación y Contabilidad, No. 83, pp. 393-416.

Carrasco, F., Caro, F.J., Correa, C., Larrinaga, C. and Páez, J.M. (1997), "Sistemas de Información para la Gestión Sostenible de la Empresa Andaluza", unpublished working paper.

Cooper, Ch. (1992), "The non and nom of accounting for (m)other nature", Accounting, Auditing \& Accountability Journal, Vol. 5 No. 1, pp. 16-39.

Deegan, C. and Rankin, M. (1996), "Do Australian companies report environmental news objectively? An analysis of environmental disclosures by firms prosecuted successfully by the environmental protection authority", Accounting. Auditing \& Accountability Iournal, Vol. 9 No. 2, pp. 50-67.

Expansión (1998), "Más de tres mil centros productivos españoles deberán adaptarse a la IPPC" 127 October.

Flavin, Ch. (1997), "The legacy of Rio”, in Worldwacht Insititute (Ed.), State of the World 1997, Earthscan, London.

Gray, R. (1990), The Greening of Accountancy. The Profession After Pearce, ACCA, London.

Gray, R. (1992), "Accounting and environmentalism: an exploration of the challenge of gently accounting for accountability, transparency and sustainability", Accounting. Organizations and Society, Vol. 17 No. 5, pp. 399-425.
Environmental accounting in Spain 
AAAJ

14,2

238
Gray, R. (1997), "The practice of silent accounting”, in Zadek, S. (Ed.), Building Corporate Accountability, Earthscan, London.

Gray, R., Walters, D., Bebbington, J. and Thompson, I. (1995), "The greening of enterprise: an exploration of the (non) role of environmental accounting and environmental accountants in organizational change", Critical Perspectives on Accounting, Vol. 6, pp. 211-39.

Gray, S.J. (1988), "Towards a theory of cultural influence on the development of accounting systems internationally", Abacus, Vol. 24 No. 1, pp. 1-15.

Greenwood, R. and Hinings, C. (1988), "Organizational design types, tracks and the dynamics of strategic change”, Organization Studies, Vol. 9 No. 3, pp. 293-316.

Guthrie, J. and Parker, L. (1989), "Corporate social reporting: a rebuttal of legitimacy theory", Accounting and Business Research, Vol. 19 No. 76, pp. 343-52.

Hofstede, G. (1991), Cultures and Organizations, McGraw-Hill, Maidenhead.

Larrinaga, C. (1995), "La relación entre las prácticas contables y el medio ambiente", $\mathrm{PhD}$ dissertation, Department of Accountancy, Universidad de Sevilla, Seville.

Laughlin, R. (1991), "Environmental disturbances and organizational transitions and transformations: some alternative models", Organizational Studies, Vol. 12 No. 2, pp. 209-32.

Lindblom, Ch. (1984), "The accountability of private enterprise: private-no: enterprise-yes", in Tinker, T. (Ed.), Social Accounting for Corporations, Markus Wiener, New York, NY.

Moneva, J.M. and Llena, F. (1996), "Análisis de la información sobre responsabilidad social en las empresas industriales que cotizan en bolsa”, Revista Española de Financiación y Contabilidad, No. 87, pp. 361-401.

Mouck, T. (1994), “Corporate accountability and Rorty's utopian liberalism”, Accounting. Auditing \& Accountability Iournal, Vol. 7 No. 1, pp. 6-30.

Näsi, J., Näsi, S., Phillips, N. and Zyglidopoulos, S. (1997), "The evolution of corporate social responsiveness", Business and Societv, Vol. 36 No. 3, pp. 296-321.

Ortí, A. (1986), "La apertura y el enfoque cualitativo o estructural: la entrevista abierta y la discusión en grupo", in García, M., Ibáñez, J. and Alvira, F. (Eds), El Análisis de la Realidad Social. Métodos y Técnicas de Investigación, Alianza Editorial, Madrid.

Páez, J.M. (forthcoming), Gestion Medioambiental y Transparencia en la Union Europea: Una Perspectiva Contable, ICAC, Madrid.

Patton, M.Q. (1990), Qualitative Evaluation and Research Methods, Sage, Newbury Park, CA.

Power, M. (1991), "Auditing and environmental expertise: between protest and professionalisation”, Accounting, Auditing \& Accountability Journal, Vol. 4 No. 1, pp. 30-42.

Puxty, A.G. (1986), "Social accounting as immanent legitimation. A critique of a technicist ideology", Advances in Public Interest Accounting, Vol. 1, pp. 95-111.

Rubenstein, D. (1992), "Bridging the gap between green accounting and the black ink", Accounting. Organizations and Societv, Vol. 17 No. 5, pp. 501-8.

Tinker, T., Lehman, Ch. and Neimark, M. (1991), "Falling down the hole in the middle of the road: political quietism in corporate social reporting”, Accounting. Auditing \& Accountabilitv Journal, Vol. 4 No. 2, pp. 28-54.

Yin, R. (1994), Case Study Research. Design and Methods, 2nd ed., Sage, Thousand Oaks, CA.

\section{Further reading}

Gibson, K. (1996), "The problem with reporting pollution allowances: reporting is not the problem", Critical Perspectives on Accounting, Vol. 7 No. 6, pp. 655-65.

Gray, R., Bebbington, J. and Walters, J. (1993), Accounting for the Environment, Paul Chapman Publishing, London. 
Hines, R. (1988), "Financial accounting: in communicating, we construct reality", Accounting Organizations and Societv, Vol. 13 No. 3, pp. 251-61.

Lehman, G. (1995), “A legitimate concern for environmental accounting”, Critical Perspectives on Accounting, Vol. 6, pp. 393-412.

Lukka, K. and Kasanen, E. (1995), "The problem of generalizability: anecdotes and evidence in accounting research", Accounting. Auditing \&Accountability Journal, Vol. 8 No. 5, pp. 71-90.

Power, M. (1992), "After calculations? Reflections on Critique of Economic Reason by André Gorz", Accounting. Organizations \& Society, Vol. 17 No. 5, pp. 477-99.

Scapens, R. (1990), "Researching management accounting practice: the role of case study methods", British Accounting Review, Vol. 24, pp. 259-81.

\section{Appendix. The cases}

In order to guarantee confidentiality a letter of the alphabet identifies each organization.

A: Medium-sized company devoted to the wholesale distribution of building material, it has a stable financial position.

B: Distribution of electrical material, it has experienced a notable growth in recent years, with over 2.5 billion pesetas turnover.

C: Recently established, this subsidiary of a multinational belongs to the car components manufacturing industry.

D: Subsidiary of a multinational, its activity of manufacturing and assembling precision materials has diminished, as a consequence of the strategy of the parent company, suffering thus an important cutback of both activity and workforce.

E: Chemical company that in recent years has suffered some problematic financial situations, from which they have recovered after a change of ownership.

F: This institution carries out a sports leisure activity, within the tourist sector, taking advantage of a magnificent natural site as a base for its commercial activity.

G: This non-profit entity operates with some 50 workers and deals with the water supply and sewerage of an Andalusian region.

H: Electrical utility, this large company, vertically integrated, maintains multiple activities and its environmental impact is significant. Therefore it deserves special attention from both the public and the administration.

I: Cooperative-type financial institution, it has an operating area restricted to a county and is found amongst the smaller Spanish financial entities.
Environmental accounting in Spain 


\section{This article has been cited by:}

1. Fernando Polo-GarridoThe Effects of the Accounting Reclassification of Members' Shares in Cooperatives: An Approach 129-149. [Abstract] [Full Text] [PDF] [PDF]

2. Lies Bouten, Patricia Everaert. 2014. Social and environmental reporting in Belgium: 'Pour vivre heureux, vivons cachés'. Critical Perspectives on Accounting . [CrossRef]

3. Emilio Passetti, Lino Cinquini, Alessandro Marelli, Andrea Tenucci. 2014. Sustainability accounting in action: Lights and shadows in the Italian context. The British Accounting Review 46, 295-308. [CrossRef]

4. Professor Charl de Villiers, Professor Jeffrey Unerman and Dr Leonardo Rinaldi, Wendy Stubbs, Colin Higgins. 2014. Integrated Reporting and internal mechanisms of change. Accounting, Auditing \& Accountability Journal 27:7, 1068-1089. [Abstract] [Full Text] [PDF]

5. Massimo Battaglia, Lara Bianchi, Marco Frey, Emilio Passetti. 2014. Sustainability reporting and corporate identity: action research evidence in an Italian retailing cooperative. Business Etbics: A European Review $\mathrm{n} /$ a-n/a. [CrossRef]

6. Cory Searcy, Ruvena Buslovich. 2014. Corporate Perspectives on the Development and Use of Sustainability Reports. Journal of Business Ethics 121, 149-169. [CrossRef]

7. Massimo Contrafatto. 2014. The institutionalization of social and environmental reporting: An Italian narrative. Accounting, Organizations and Society . [CrossRef]

8. Stefan Schaltegger, Dimitar ZvezdovIn control of sustainability information: Untangling the role of accountants 265-296. [Abstract] [Full Text] [PDF] [PDF]

9. Ionel-Alin IenciuEnvironmental disclosure of romanian listed entities 235-254. [Abstract] [Full Text] $[\mathrm{PDF}][\mathrm{PDF}]$

10. Massimo Contrafatto, John Burns. 2013. Social and environmental accounting, organisational change and management accounting: A processual view. Management Accounting Research 24, 349-365. [CrossRef]

11. Lies Bouten, Sophie Hoozée. 2013. On the interplay between environmental reporting and management accounting change. Management Accounting Research 24, 333-348. [CrossRef]

12. Teresa Pereira Eugénio, Isabel Costa Lourenço, Ana Isabel Morais. 2013. Sustainability strategies of the company TimorL: extending the applicability of legitimacy theory. Management of Environmental Quality: An International Journal 24:5, 570-582. [Abstract] [Full Text] [PDF]

13. George Ted Khiong Thien. 2013. CSR for Clients' Social/Environmental Impacts?. Corporate Social Responsibility and Environmental Management n/a-n/a. [CrossRef]

14. María Luisa Pajuelo Moreno. 2013. Assessment of the Impact of Business Activity in Sustainability Terms. Empirical Confirmation of its Determination in Spanish Companies. Sustainability 5, 2389-2420. [CrossRef]

15. Lisa Jack, Julia Mundy, Erik R. Strauss, Pascal Nevries, Juergen Weber. 2013. The development of MCS packages - balancing constituents' demands. Journal of Accounting \& Organizational Change 9:2, 155-187. [Abstract] [Full Text] [PDF]

16. Basil Tucker. 2013. Environmental disturbances, organizational transitions and transformations: A view from the dark side. Critical Perspectives on Accounting 24, 242-259. [CrossRef]

17. Janice Bell, Zahirul Hoque, Paulina Arroyo. 2012. Management accounting change and sustainability: an institutional approach. Journal of Accounting \& Organizational Change 8:3, 286-309. [Abstract] [Full Text] [PDF] 
18. Michael Mitchell, Allan Curtis, Penny Davidson. 2012. Can triple bottom line reporting become a cycle for "double loop" learning and radical change?. Accounting, Auditing \& Accountability Journal 25:6, 1048-1068. [Abstract] [Full Text] [PDF]

19. Amanda Ball, Vernon Soare, Joanna Brewis. 2012. Engagement Research in Public Sector Accounting. Financial Accountability \& Management 28:10.1111/faam.2012.28.issue-2, 189-214. [CrossRef]

20. Antonis Skouloudis, Konstantinos Evangelinos. 2012. A research design for mapping national CSR terrains. International Journal of Sustainable Development \& World Ecology 19, 130-143. [CrossRef]

21. Michael Fraser. 2012. "Fleshing out" an engagement with a social accounting technology. Accounting, Auditing \& Accountability Journal 25:3, 508-534. [Abstract] [Full Text] [PDF]

22. Garry D. Carnegie, Rob Gray, Richard Laughlin. 2012. It was 20 years ago today. Accounting, Auditing \& Accountability Journal 25:2, 228-255. [Abstract] [Full Text] [PDF]

23. Mónica Hernández-Madrigal, María-Isabel Blanco-Dopico, Beatriz Aibar-Guzmán. 2012. The influence of mandatory requirements on risk disclosure practices in Spain. International Journal of Disclosure and Governance 9, 78-99. [CrossRef]

24. Maider Aldaz Odriozola, José Antonio Calvo Sánchez, Igor Álvarez Etxeberria. 2012. Divulgación de información sobre corrupción: empresas del IBEX 35. Revista de Contabilidad 15, 59-90. [CrossRef]

25. Patricia Horrach, Antoni Socias Salvà. 2011. La actitud de las empresas de economía solidaria frente a la divulgación de información sobre sostenibilidad desde el prisma de la teoría de los stakeholders o grupos de interés. Revista de Contabilidad 14, 299-320. [CrossRef]

26. Patricia Horrach, Antoni Socias Salvà. 2011. La actitud de las empresas de economía solidaria frente a la divulgación de información sobre sostenibilidad desde el prisma de la teoría de los stakeholders o grupos de interés. Revista de Contabilidad 14, 267-297. [CrossRef]

27. Carmen Correa. 2011. Unveiling Social and Environmental Accounting Research in Spain: A Narrative of the Mobilisation of the Spanish Academic Community. Social and Environmental Accountability Journal 31, 49-62. [CrossRef]

28. Lee D. Parker. 2011. Twenty-one years of social and environmental accountability research: A coming of age. Accounting Forum 35, 1-10. [CrossRef]

29. Kaushik Sridhar. 2011. A multi-dimensional criticism of the Triple Bottom Line reporting approach. International Journal of Business Governance and Etbics 6, 49. [CrossRef]

30. Sónia Maria da Silva Monteiro, Beatriz Aibar-Guzmán. 2010. Organizational and accounting change within the context of the environmental agenda. Journal of Accounting \& Organizational Change 6:4, 404-435. [Abstract] [Full Text] [PDF]

31. Teresa Eugénio, Isabel Costa Lourenço, Ana Isabel Morais. 2010. Recent developments in social and environmental accounting research. Social Responsibility Journal 6:2, 286-305. [Abstract] [Full Text] [PDF]

32. Amanda Ball, Russell Craig. 2010. Using neo-institutionalism to advance social and environmental accounting. Critical Perspectives on Accounting 21, 283-293. [CrossRef]

33. Ulla Kotonen. 2009. Formal corporate social responsibility reporting in Finnish listed companies. Journal of Applied Accounting Research 10:3, 176-207. [Abstract] [Full Text] [PDF]

34. Professor Jan Bell, Professor Zahirul Hoque, Matthew Egan. 2009. Sydney water sector change and industrial water management. Journal of Accounting \& Organizational Change 5:2, 277-293. [Abstract] [Full Text] [PDF] 
35. Jan Bebbington, Colin Higgins, Bob Frame. 2009. Initiating sustainable development reporting: evidence from New Zealand. Accounting, Auditing \& Accountability Journal 22:4, 588-625. [Abstract] [Full Text] $[\mathrm{PDF}]$

36. Carol A. Adams, Glen Whelan. 2009. Conceptualising future change in corporate sustainability reporting. Accounting, Auditing \& Accountability Journal 22:1, 118-143. [Abstract] [Full Text] [PDF]

37. Rob Gray, Dave Owen, Carol AdamsSome theories for social accounting?: A review essay and a tentative pedagogic categorisation of theorisations around social accounting 1-54. [Abstract] [Full Text] [PDF] [PDF]

38. Kate Grosser, Jeremy Moon. 2008. Developments in company reporting on workplace gender equality?. Accounting Forum 32, 179-198. [CrossRef]

39. Carol A. Adams. 2008. A commentary on: corporate social responsibility reporting and reputation risk management. Accounting, Auditing \& Accountability Journal 21:3, 365-370. [Abstract] [Full Text] [PDF]

40. Michael Mitchell, Allan Curtis, Penny Davidson. 2008. Evaluating the process of triple bottom line reporting: Increasing the potential for change1. Local Environment 13, 67-80. [CrossRef]

41. Lee Parker, James Guthrie, Markus Milne, David Owen. 2008. Chronicles of wasted time?. Accounting, Auditing \& Accountability Journal 21:2, 240-267. [Abstract] [Full Text] [PDF]

42. Sue Llewellyn, Markus J. Milne, Crawford Spence. 2007. Social and environmental reporting and hegemonic discourse. Accounting, Auditing \& Accountability Journal 20:6, 855-882. [Abstract] [Full Text] [PDF]

43. Jan BebbingtonChanging organizational attitudes and culture through sustainability accounting 226-242. [CrossRef]

44. John C. Dumay, James Guthrie. 2007. Disturbance and implementation of IC practice: a public sector organisation perspective. Journal of Human Resource Costing \& Accounting 11:2, 104-121. [Abstract] [Full Text] [PDF]

45. Carol A. Adams, Carlos Larrinaga-González, Esther Albelda Pérez, Carmen Correa Ruiz, Francisco Carrasco Fenech. 2007. Environmental management systems as an embedding mechanism: a research note. Accounting, Auditing \& Accountability Journal 20:3, 403-422. [Abstract] [Full Text] [PDF]

46. Carol. A. Adams, Carlos Larrinaga-González, Ataur Rahman Belal, David L. Owen. 2007. The views of corporate managers on the current state of, and future prospects for, social reporting in Bangladesh. Accounting, Auditing \& Accountability Journal 20:3, 472-494. [Abstract] [Full Text] [PDF]

47. Carol A. Adams, Carlos Larrinaga-González, Carol A. Adams, Carlos Larrinaga-González. 2007. Engaging with organisations in pursuit of improved sustainability accounting and performance. Accounting, Auditing \& Accountability Journal 20:3, 333-355. [Abstract] [Full Text] [PDF]

48. Carol A. Adams, Carlos Larrinaga-González, Carol A. Adams, Patty McNicholas. 2007. Making a difference. Accounting, Auditing \& Accountability Journal 20:3, 382-402. [Abstract] [Full Text] [PDF]

49. Rob Gray. 2006. Does sustainability reporting improve corporate behaviour?: Wrong question? Right time?. Accounting and Business Research 36, 65-88. [CrossRef]

50. José M. Moneva, Pablo Archel, Carmen Correa. 2006. GRI and the camouflaging of corporate unsustainability. Accounting Forum 30, 121-137. [CrossRef]

51. James Guthrie, Indra Abeysekera. 2006. Content analysis of social, environmental reporting: what is new?. Journal of Human Resource Costing \& Accounting 10:2, 114-126. [Abstract] [Full Text] [PDF] 
52. Carol Ann Tilt. 2006. Linking environmental activity and environmental disclosure in an organisational change framework. Journal of Accounting \& Organizational Change 2:1, 4-24. [Abstract] [Full Text] [PDF]

53. Carlos Larrinaga González, Antoni Llull Gilet, Miguel Perelló Julià. 2006. El papel de la información medioambiental en el cambio organizativo: el caso del sector turístico balear. Spanish Journal of Finance and Accounting / Revista Española de Financiación y Contabilidad 35, 501-522. [CrossRef]

54. Manuel Fernández Chulián, Carlos Larrinaga González. 2006. Percepciones Sobre Contabilidad de Costes Ecológicos Completos: Análisis Empírico en el Sector Energético Español. Spanish Journal of Finance and Accounting / Revista Española de Financiación y Contabilidad 35, 225-254. [CrossRef]

55. Amanda Ball. 2005. Environmental accounting and change in UK local government. Accounting, Auditing \& Accountability Journal 18:3, 346-373. [Abstract] [Full Text] [PDF]

56. Tanya M. Lee, Paul D. Hutchison. 2005. The Decision to Disclose Environmental Information: A Research Review and Agenda. Advances in Accounting 21, 83-111. [CrossRef]

57. Brendan O'Dwyer. 2005. Stakeholder democracy: challenges and contributions from social accounting. Business Ethics: A European Review 14:10.1111/beer.2005.14.issue-1, 28-41. [CrossRef]

58. Bernabé Escobar Pérez, Antonio Lobo Gallardo, Cristina M. Rocha Martínez de la Peña. 2005. La Investigación Empírica en Contabilidad de Gestión en España: Análisis de las Publicaciones Españolas. Spanish Journal of Finance and Accounting / Revista Española de Financiación y Contabilidad 34, 183-210. [CrossRef]

59. Anthony J. Berry, David T. OtleyCase-Based Research in Accounting 231-255. [CrossRef]

60. Brendan O’Dwyer. 2003. Conceptions of corporate social responsibility: the nature of managerial capture. Accounting, Auditing \& Accountability Journal 16:4, 523-557. [Abstract] [Full Text] [PDF] 